Revista Mídia e Cotidiano

Artigo Seção Temática

Volume 13, Número 2, agosto de 2019

Submetido em: 27/06/2019

Aprovado em: 08/08/2019

\title{
Transfiguração e Sexualidade: a herança "suja" de Michel Maffesoli para os estudos do cotidiano
}

\section{Transfiguration and Sexuality: the "dirty" heritage of Michel Maffesoli for studies of everyday life}

\author{
Marcello Monteiro GABBAY ${ }^{1}$
}

\begin{abstract}
Resumo
O presente texto apresenta uma sucinta revisão do pensamento de Michel Maffesoli sobre o cotidiano, a transfiguração do político e a cultura subterrânea, para posteriormente ensaiar uma observação à moda maffesoliana dos recentes fenômenos de ascensão do conservadorismo no plano das instituições políticas e da produção de discursos de ruptura e resistência no âmbito da canção popular, especificamente quanto às temáticas ligadas às sexualidades. O objetivo é revistar e apropriar o pensamento de Michel Maffesoli para além do já tradicional conceito de "tribos", e a partir de questões extraídas do cenário social contemporâneo.
\end{abstract}

Palavras-chave: Michel Maffesoli; música popular; cotidiano; resistência; transfiguração do político.

\begin{abstract}
This article presents a brief overview of Michel Maffesoli's thoughts on everyday life, the transfiguration of politics, and the culture of underground society. Then, it adopts a Maffesolian angle to observe the recent phenomena of political institutions' growing conservative wave as well as the production of rupture and resistance discourses in the popular music scenario with a specific focus on sexuality themes. Our goal is to revisit and appropriate Michel Maffesoli's thoughts, going beyond the traditional concept of "tribes", and taking into account issues from the contemporary social context.
\end{abstract}

Keywords: Michel Maffesoli; popular music; everyday life; resistance; transfiguration of politics.

\footnotetext{
${ }^{1}$ Doutor e Mestre em Comunicação e Cultura pela UFRJ, com estágio sanduíche na Université ParisDescartes. Especialista em Musicoterapia Preventiva e Social pela FMU (SP). Professor da Universidade São Judas Tadeu. E-mail: marcellogabbay@uol.com.br
} 


\section{míDiA \\ eco DiAno}

\section{Maffesoli e a transfiguração do político}

Ao se aposentar da Faculdade de Sociologia da Sorbonne em 2012, o sociólogo francês Michel Maffesoli deixava a cadeira de Émile Durkheim, que ocupou simbolicamente desde que sucedeu a seu mestre Gilbert Durand. A suposta desobediência para com o legado ortodoxo de Durkheim sempre aborreceu alguns de seus colegas, que cultivavam no fantasma do pai da sociologia francesa exatamente aquilo que Maffesoli mais combateu: a autoridade da cátedra. A busca por uma sociologia de baixo, que deslocasse o olhar para os acontecimentos do cotidiano foi levada a fundo por Michel Maffesoli. Arriscaríamos sugerir que ele foi mais longe que seu mestre, Gilbert Durand, transformando o tema de sua vida - em mais de trinta livros publicados em torno do mesmo problema de fundo - em uma espécie de busca pessoal.

São várias as histórias contadas por seus amigos e continuadores no Brasil, Juremir Machado da Silva, no Sul, Armindo Bião na Bahia, João de Jesus Paes Loureiro na Amazônia. Causos de um sociólogo em busca da experiência em caminhadas, terreiros, festas, feiras e tantas aventuras, tendo no Brasil um de seus mais importantes "laboratórios", como ele mesmo costuma afirmar.

A obra que coroa a aposentadoria de Maffesoli "O Conformismo dos Intelectuais" (2013) lança fogo sobre aquelas que ele considerava as estruturas fundamentais da Modernidade: a imprensa, a política e a escola. Por detrás de uma visão combativa, e por vezes poética, as referências fundamentais do pensamento maffesoliano se embebem de Friedrich Nietzsche, Michel Foucault e Gustav Jung. Nestes pilares, conceitos transfigurados se transformam no "vitalismo tribal", na crítica às instituições e no conflito entre os arquétipos do "pai" e da "grande mãe". Assim como Jung advertiu em sua última obra e autobiografia, que todo terapeuta tinha de antes dominar o estudo das mitologias, todo sociólogo do cotidiano deveria dominar o pensamento junguiano. Pois é na decadência do arquétipo moderno do "pai" e na ascensão subversiva dos arquétipos do feminino que repousa o conflito fundamental do pensamento maffesoliano. Não à toa, o joguete de palavras "invaginação dos sentidos", que Maffesoli apresenta aqui e ali já há cerca de dez anos: 
Talvez, para além desses valores ativos, quiçá ativistas, esses da construção da direção e da dominação (de si e do mundo), será preciso saber retornar ao nada fundador, ao fundo natural, ao dado protetor e matricial. É a isto que denominei a invaginação dos sentidos. Ir além do substancial, do ser que é nomeado, ou seja, além das entidades estáveis e certas de si-mesmas: Deus, Estado, Instituição, Indivíduo, o retorno curioso de uma aspiração ao vazio criador (MAFFESOLI, 2010, p. 78$)^{2}$.

Pois as instituições fundadas na Modernidade reproduziam o espírito paterno daquele tempo. Muniz Sodré, em seu livro que primeiro se aproxima das temáticas próprias do mundo de Maffesoli, "As Estratégias Sensíveis" (2006), inaugura seu segundo capítulo realizando uma analogia entre a estranha ascensão de Hitler na Alemanha com um sentimento arquetípico de orfandade, sendo a nação alemã do préguerra o ente feminino. Hitler encarnava ali o pai austero, ríspido, frio, mas eficaz. O Holocausto nazista talvez seja o símbolo máximo da decadência Moderna, que mobilizou Foucault, Sartre, Agamben, Habermas, Adorno e todos os seus, dentre tantos filósofos em busca de uma explicação "superior". Analogias já foram feitas com grandes catástrofes modernas, o escravismo na América, a guerra do Vietnã, a islamofobia, etc. Mas por debaixo de todos estes acontecimentos, reside um processo de transfiguração das formas do social que vêm do cotidiano. Pois é de baixo que começa a ruir um sistema social maior, como a lenda da cobra grande, o grande animal feminino que repousa sob a terra na iminência de um despertar destruidor. A transfiguração de modelos sociais é perturbadora, mas aponta para o desgaste e a insustentabilidade do modelo então vigente.

Na época das manifestações populares de 2011, 2012 e 2013, que reuniu no mesmo caldeirão o Occupy Wall Street, a Primavera Árabe e as Jornadas de Junho no Brasil, Maffesoli comentou em entrevista ao Jornal Zero Hora, de Porto Alegre ${ }^{3}$, que, invés de estes acontecimentos recuperarem o caráter revolucionário popular da ideologia política marxista, eles afirmavam o aspecto fragmentário e subterrâneo da sociedade contemporânea. Por debaixo das bandeiras, hinos e passeatas, uma miríade de pautas, formatos, causas e desejos, e a força do cotidiano.

\footnotetext{
${ }^{2}$ Traduzido do original em francês pelo autor.

${ }^{3}$ Disponível em: <https://gauchazh.clicrbs.com.br/cultura-e-lazer/noticia/2013/04/sociologo-michelmaffesoli-fala-da-retomada-de-manifestacoes-juvenis-4105060.html>. Acesso em: jun. 2019.
} 
Pois são várias e variadas as pautas que hoje caracterizam as sociedades. O caráter da sociologia do cotidiano é então perceber e escutar o que vem de baixo. E o que vem são inúmeras tentativas de transfiguração do social, novas formas de comunicar-se, de habitar, de se expressar, de família, de comunidade, de cultura e de política. Na “Transfiguração do Político" (2005c, p. 27), livro consumido menos do que o necessário para o entendimento da política na visão de Maffesoli, o autor afirma que "a gestão das paixões é certamente a arte suprema de toda boa política”. Pois, desde o Império Romano, a configuração da hierarquia política fora baseada num "sentimento 'religioso' de pertencer coletivamente ao imperium mundi" (MAFFESOLI, 2005c, p. 32-39), à ordem da civilização romana, donde se originou o conceito atual de política como gestão das sociedades a partir de um sistema de poder institucional, mas sustentado por um tipo de sentimento vinculativo de base afetiva. Acontece que esta base se transfigurou e passa pela ressaca da deslegitimização da antiga política para buscar novas formas de configuração da cidade e do social. Se a antiga política se apropriou da ideologia monoteísta e de todo pensamento monotônico - as monoculturas de plantio, os monopólios industriais, as monogamias na família - a política transfigurada busca a diversidade e a heterogeneidade.

E uma das formas mais contundentes na nova política do cotidiano, que reúne todos os aspectos da visão maffesoliana, quais sejam, a festa, os corpos, as produções de vínculo, o tribalismo e o desejo de comunicação, são as questões da sexualidade.

$\mathrm{Na}$ "História da Sexualidade" de Michel Foucault (2017, p. 105), as resistências são apresentadas mais como formas de insurgências "de baixo", que se apresentam sob variadas maneiras, mais ou menos contundentes do ponto de vista macrossocial. Isto significa pensar a resistência como processos de ruptura que se manifestam de formas variadas. Toda a querela em torno do pensamento maffesoliano está na ideia que atribuem a ele como um sociólogo que rejeita o político. Na verdade, o que provoca a repulsa do autor é a institucionalização burocrática do político. A transfiguração do político é um retorno metodológico à observação das variadas formas de ruptura. O político deverá perdurar a partir de sua (re)ligação com o "substrato das sensibilidades que o fundamentam", o "solo do sensível" partilhado e fundador de uma estética coletivizante e criativa, afirma Maffesoli (2005b, p. 87, 189). 
Assim, no contexto das grandes manifestações em torno das eleições presidenciais que culminaram na consolidação do novo conservadorismo no Brasil, estar na rua, a co-presença, os beijaços, as batucadas, as insurgências mais brutais seriam todas manifestações da micropolítica de baixo.

É precisamente aí que se localiza também a memória coletiva, as (micro) histórias, diferentes da História universal. Portanto, Maffesoli (2006, p. 124-125) alerta que a institucionalização da política é uma forma inventada no contexto das sociedades Modernas. Hoje, a política como produção do vínculo "subterrâneo" não passaria mais pelos antigos formatos institucionalizados. No lugar dos processos existentes na ordem do político e do individualismo, "vemos aparecer estruturas de comunicação ao mesmo tempo intensivas e reduzidas no espaço. Esses agrupamentos afinitários retomam a antiga estrutura antropológica que é a 'família ampliada"'.

Porém, outro fenômeno recente tem sido tema das releituras maffesolianas: a insurgência conservadora nas macropolíticas globais. Sobre o conservadorismo na política institucional, Maffesoli (2013) apresenta uma visão que acaba por reforçar sua hipótese mais recente quanto à decadência da grande política.

\section{Conservadorismo: a última face do arcaísmo moderno}

A Parada Gay de 2018 em São Paulo reencenou sua tradicional festa na avenida Paulista, sempre marcada pela inflexão política. Festa e ativismo são instâncias coligadas. No entanto, o tema do ano era: "Poder pra LGBTQI+, nosso voto, nossa voz". Inteligentemente, a organização do movimento pensa na tomada de espaço. Mais Deputados, Vereadores e Senadores que carreguem consigo a pauta LGBTQI+. Se por um lado, há um desejo de colorir as instâncias legislativas cada vez mais, a transmissão da votação do encaminhamento do Impeachement de Dilma Roussef na Câmara dos Deputados em 2016 evidenciou outro dado: as instituições legislativas são essencialmente conservadoras.

A eleição de Donald Trump nos Estados Unidos, a ascensão conservadora que assombrou a França com a possibilidade de Marine Le Pen, da Frente Nacional, para presidente. A eleição de João Dória em São Paulo em primeiro turno, e a ascensão de Jair Bolsonaro como fenômeno da Internet e como presidente da república no Brasil em 2019. 
Todos estes fatores e muitos outros têm em comum uma espécie de levante fascista travestido de positivista e conservador. O recurso discursivo mais comum destas personalidades é a crítica dura aos direitos humanos, às políticas sociais de atendimento a imigrantes, indígenas, negros e moradores de rua de um lado, e o elogio ao trabalho resignado e aos direitos individuais de outro. Este cenário representa uma cisão profunda no espírito do tempo. Porém, ao invés de simbolizar a manutenção firme do autoritarismo, trata-se na verdade do esfacelamento de toda a estrutura societal criada na Modernidade. E não nos referimos apenas ao contrato social e ao Estado, ao contrário, referimo-nos àquilo que estes totens coletivos escondiam em sua sombra: a manutenção do paradigma patriarcal e conservador.

A decadência da política moderna se refere menos à necessidade prática de desconfiguração do Estado do que à anacronia do pensamento moderno baseado no progresso, no trabalho, na família centrada no patriarca e na cidade fundada no sistema centro-periferia, dentre outros tantos símbolos. É esta estrutura de fundo que deu sentido aos séculos de escravidão negra nas Américas, ao Holocausto na Europa, ao Apartheid na África e à guerra ao Islã no Oriente Médio. Trata-se de confinar ao "outro" a sombra coletiva da moral moderna. A ascensão do conservadorismo dos Estados Unidos ao Paraná simboliza um movimento de resistência do pensamento moderno, um desejo de sobrevivência do arcaico diante de sua própria decadência.

Em 2012, Michel Maffesoli (2013, p. 21) tratava do desaparecimento dos chamados bien-pensants (intelectuais, intelligentsia, etc), e de sua substituição por outros atores da vida social. Os antigos bien-pensants estão cada vez mais distantes da vida comum, corrente, do dia-a-dia; no que favorece o surgimento de discursos extremistas e demagógicos arcaicamente preocupados com a imposição moral e ideológica do velho pensamento que conservou a estrutura de classes e o racismo nos séculos passados.

Assim, existe de um lado o ideário moderno, todo ele erguido no seio de uma comunidade de classe, as burguesias europeias dos séculos XVII ao XIX, depois suplantadas pelas elites empresariais da atualidade; e de outro a complexa teia de visões de mundo pós-globalização, alimentadas por uma miríade de constituições comunitárias, tribais, místicas, artísticas, territoriais, etc. A diferença é que no segundo caso percebe-se uma complicada co-existência de ideias, causas e visões na esfera pública, todas elas 


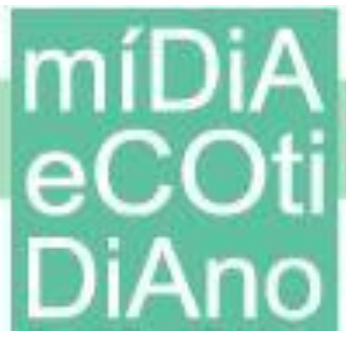

constituídas nos fundos das sociedades: no cotidiano. O que atrapalha o entendimento destes pensamentos de base, destas formas sociais contemporâneas, é a ilusão de um futuro melhor (forma profana da "Cidade de Deus" de Santo Agostinho) propagada pelos progressistas, afirma Maffesoli (2013, p. 39). Este futuro se espelha nos paradigmas do trabalho, da acumulação e do direito civil; dispositivos que vêm sendo ressignificados pelo grande capital. No caso brasileiro, as reformas trabalhistas recentes, que flexibilizam a favor das empresas a dinâmica do trabalho, deixando o trabalhador mais vulnerável aos humores do sistema produtivo; também o encarecimento do custo de vida nas grandes cidades, resultado do capitalismo especulativo; e por fim o clima de questionamento dos direitos civis básicos por meio do discurso da livre concorrência, que põe em cheque, por exemplo, o direito à livre circulação com políticas de pedágio e privatização dos sistemas de transporte público, e dos projetos de privatização da educação e de fomento à cultura.

Este esmagamento da vida nas grandes cidades comprime as formas de produção de cidadania baseadas no espaço público, uma vez que este estaria na mira do capital especulativo e das privatizações. Por outro lado, a vigilância e a denúncia que recaem sobre o humano, demasiado humano provêm de uma ideia de justiça social erigida no século passado, endossada pelo jornalismo, pela mídia e pelo meio político. $\mathrm{O}$ afã de erradicar a corrupção e a mentira acabam por instalar um clima generalizado de espionagem e desconfiança. Da mesma forma, nas universidades e agências de fomento à pesquisa, busca-se denunciar o "perigo do obscurantismo". "O espírito do padre não está morto", afirma Maffesoli (2013, p. 44-45). A inquisição se empenha em denunciar a "falha" intelectual e a "incorreção" metodológica, temática e epistemológica. O espírito conservador advoga em favor de uma pureza moral utópica da qual ele mesmo carece. Exemplo deste pensamento, no Brasil, são as discussões sobre a não obrigatoriedade de disciplinas da área de Humanas no ensino médio. Não há brecha para a sombra, para o terreno do obscuro na vida social. Por outro lado, "é exatamente a aceitação do claroescuro da existência pela opinião pública que a torna tão inatingível aos diversos protagonistas da opinião publicada"4 (MAFFESOLI, 2013, p. 50).

\footnotetext{
${ }^{4}$ Traduzido do original em francês pelo autor.
} 
O que Maffesoli (2013, p. 59) entende por "pertencimentos comunitários" não tem nenhuma relação com a ideia moderna de comunidades tradicionais descritas pelo pensamento político, pois se funda na diversidade. Contra o universalismo da Razão, o relativismo das singularidades e a ambiguidade.

Trata-se aqui de refletir sobre o que configura a produção de um pensamento. Até o momento, o "pensamento autêntico" ou legítimo passava pela construção de um conjunto de dogmas atrás do que se mantinha determinada classe autodeclarada guardiã das ideias. Defende-se aqui que, ao contrário, o pensamento é tudo aquilo produzido a partir do enraizamento no cotidiano. O pensamento em processo constante de renovação é o amálgama da comunidade. Exemplo contemporâneo são as irresolutas discussões sobre a luta por igualdade de gênero, as várias mudanças na sigla que inclui as “comunidades" de gênero. A luta por direitos e representação não está nunca resolvida, é sempre transfigurativa, isto porque parte de baixo, da vida vivida.

Estão em cena dois arquétipos sociais: de um lado os "intelectuais orgânicos", tradutores dos anseios oriundos do cotidiano, conectados diretamente com a vida nas ruas, com as dificuldades e manobras do viver; de outro lado, o típico cidadão médio, tendente ao sedutor pensamento conservador como forma de manutenção da boa moral, apegado aos valores construídos na Modernidade sobre classe, família e cidade.

Quando da eleição de Donald Trump, em 2016, o texto de Guilhaume Gendron, do jornal Libération, de 8 de dezembro ${ }^{5}$, apontava uma insurgência de direita em escala global, o que Gendron classifica ali como uma "contra-revolução cultural" liderada pelo bourgeois bourrin, o burguês rústico, desinformado, grosseiro, em oposição ao imaginário francês de burguês boêmio, associado ao ideário da revolução de 1789 . Este novo burguês renega o ideário moderno associado à intelectualidade universitária que o sucedeu, representado pelo tripé: ecologia, humanismo e justiça social.

Esta glorificação do burguês "bruto" associada a uma suposta defesa do direito de pensar e fazer, ou seja, o que esta categoria entende por "liberdade de expressão", é nada mais que uma forma torta do direito individual pregado pela ideologia

\footnotetext{
${ }^{5}$ Disponível em: <http://next.liberation.fr/vous/2016/12/08/les-boubours-bobos-a-rebours_1533938>. Acesso em: 07 jun. 2019.
} 


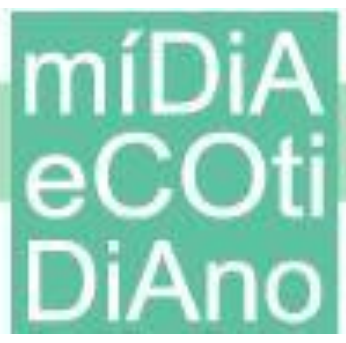

liberal. Trata-se, como salienta o jornalista francês, mais de um projeto de pensamento mais amplo do que simplesmente de uma personagem cômica. Uma visão de mundo que prima pelo direito individual de exercer a opinião separatista e racista.

Este personagem encarna o típico sujeito da decadência Moderna: apegado aos modelos morais e sociais do século XIX, temente das questões "obscuras" da sexualidade, da cultura e das identidades, o típico conservador dos tempos atuais.

Por outro lado, no Brasil, a agonia de renovação das esquerdas, em busca de se fazerem representativas dos anseios da juventude urbana, a nova intelectualidade das ruas, cujos símbolos vão do grafite e das políticas de igualdade de gênero até as consequências ambientais da hidrelétrica de Belo Monte e da temerária aprovação do relatório de flexibiliza o uso de agrotóxicos no país, se reflete mais na tentativa de renovação das personagens políticas do que na forma do político. De todo modo, contra o conservadorismo representado pelo discurso radical de personagens como Trump e Bolsonaro, faz-se necessária a insurgência de lideranças mais orgânicas e representativas do desejo de transfiguração das formas do social e da cidadania.

Mas antes, seria preciso regressar à profunda ferida cultural da vida brasileira: o espírito escravocrata, que historicamente relegou o conceito de cidadania à condição de classe e a critérios raciais complexos.

Por outro lado, a perspectiva maffesoliana aponta, como já mencionamos, para as produções de rupturas no cotidiano. O nosso ponto de partida na "sociologia do cotidiano" coloca-nos diante do fato social, dos processos coletivizantes e comunicacionais ordinários, comuns, amparados em rituais e práticas da rua, do terreiro, dos becos e esquinas, e no imaginário engendrado nestas relações. A virada do endurecimento racionalista provocado pelas leituras marxistas - notadamente pós-Marx - encontra no texto tardio de Marcuse ([1977], 2007, p. 15) sobre a dimensão estética da arte, a proposição de um valor que não esteja rigidamente preso à esfera material da prática criativa ou expressiva, mas que observa nas "forças não materiais" um papel socializante. O que se compreende como o imaginário é o plano do duplo da realidade provocado pela prática e pelas narrativas do cotidiano, e que possui um grau de concretude tão contundente quanto as dimensões econômico-políticas da vida social, e 


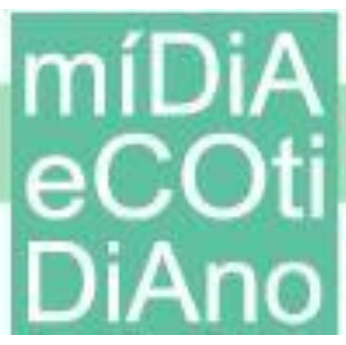

que, portanto, possui um valor comunicacional concreto no âmbito cotidiano das relações; quer dizer, possui parte determinante nos fenômenos comunitários e sociais.

Para Marcuse ([1977], 2007, p. 17-27), a força vitalizante que renasce em Eros seria a base de toda solidariedade e sentimento comunitário. Contemporaneamente, a "sombra de Dionísio" de Maffesoli (2005a, p. 72-73, 88-89, 92, 103), instauradora da desordem e da perturbação através do escárnio, tem no corpo uma sede das sensações, tanto do desejo, como da imaginação, que provoca da mesma forma um ressurgimento do instinto vitalizante e vinculativo.

Pois é na canção popular que se produzem variadas formas de ruptura do social. Seja pela canção como discurso, seja pelos usos que se dão a ela na vida cotidiana. O valor gerado por essa experiência comum compõe uma potência criativa e religadora da cultura, um novo valor do estar-junto, do território e da comunicação, cujo cimento é a emoção coletiva, que vem à tona e toma corpo, objetivamente, em formas as mais diversas, sendo a que nos interessa aqui é a poética corporal, musical, performática da canção popular em sua manifestação mais baixa e cotidiana.

\section{Maffesoli Hoje: por um espaço "sujo" no cotidiano}

Como vimos até agora, a cultura do cotidiano é o grande tema da herança teórica de Maffesoli, pois é no domínio do cotidiano que se observam rupturas, resistências, reinvenções e tentativas que poderiam indicar novas formas do social. Mas, para além do interesse sociológico na cultura do cotidiano, a herança de Maffesoli aponta para o que há de mundano, dionisíaco, portanto, criativo e transgressor, no cotidiano.

No âmbito da música popular, certos usos da canção evocam a produção de discursos os mais variados, que se manifestam no cotidiano na forma de reocupação dos espaços públicos, das ruas, da noite, etc. $\mathrm{O}$ embate fervoroso entre a apropriação da música popular pelo mercado - e apropriação da rua, dos festejos, festivais, batuques, etc. é igualmente perversa - e a resistência cada vez mais marginalizada de manifestações marcadas pelo espírito comum da carnavalização - teatralização dionisíaca - aponta, por outro lado, para um desejo de repressão da força dionisíaca da música; como se o "sujo" e o "baixo" no popular revelassem uma nudez social insuportável; um estado de "natureza corrompida" ou pecado, como proposto por Agamben (2009, p. 108). Essa condição 


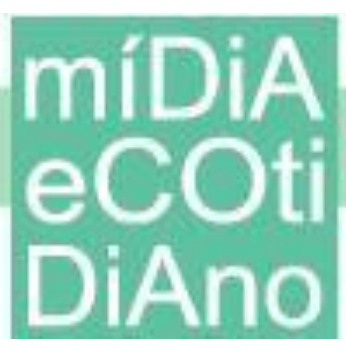

"defectada" - palavra de Agamben - da nudez, e em nosso caso, do cantar, dançar e batucar, oprimiu durante a insurgência cristã e a Modernidade a força vinculativa e erótica - o erótico no sentido aproximativo e relacional como dado por Maffesoli (2012) ou ainda por Byung-Chul Han (2017). Esta força vinculativa, produtora do comum, é, reafirmo, baixa, suja, cotidiana e transfigurativa.

Assim, a canção popular em sua forma ousada e desviante acaba servindo como fio tradutor do desejo coletivo de determinadas comunidades. É mais o caso do repertório mundano, quase infame, de MC Linn da Quebrada, ou do cantar naif de Alípio Martins em Piranha, do que das tentativas do mercado de reproduzir as cenas subversivas formadas no cotidiano. É o desvio, o desencaixe, que caracteriza a força do contemporâneo. O contemporâneo na cultura popular - as vanguardas populares - e no comunitarismo sociopolítico estarão voltados para organizar o discurso dos desencaixados. Para Agamben (2009, p. 22), ser atual é uma condição sempre anacrônica.

A vinculação comunitária é então uma experiência contraditória, cambiante e “suja”. Não à toa, Jesús Martín-Barbero, o entusiasta da pesquisa de recepção e da cultura popular latino-americana, costuma dizer que a pesquisa requer "sujar as mãos" na vida cotidiana. Vale ressaltar também a proposição de uma comunidade "pós-social" de Martin Buber (2008), ancorada na relação mais instintiva e criativa entre as pessoas, e baseada na relação de sentido entre o "eu" e o "tu". E a esta forma de relação não atribuímos tonalidade romântica, ao contrário, superado o idealismo aristotélico, que ainda assim forneceu as bases de um desejo por uma polis baseada na relação e na solidariedade, pensamos a vida nas cidades como a possibilidade do confronto. O que há de diversidade na cidade - o próprio sentido do "outro" - é a possibilidade de inclusão da negatividade. “Onde vige o puramente positivo, o excesso de positividade, ali não há espírito", afirma o filósofo coreano Byung-Chul Han (2012, p. 46). O autor está se referindo à perda do eros na vida social.

O neoliberalismo, com seus impulsos do eu e de desempenho desenfreados, é uma ordem social da qual o eros desapareceu totalmente. A sociedade da positividade, donde se ausentou a negatividade da morte, é uma sociedade do mero viver, dominada pela única preocupação de "assegurar a sobrevivência na descontinuidade." (HAN, 2012, p. 52). 
Se por um lado é pertinente a crítica a uma ideia de sociedade sustentada sobre uma positividade "pura", marcada pelo desejo do progresso, da aniquilação da feiura, da imagem da miséria (e não da miséria estrutural), pela renovação imobiliária que suplanta a memória arquitetônica dos centros urbanos, e pelas medidas eugenistas que vão desde a privatização dos transportes, parques e espaços públicos, até o modelo repressivo de policiamento nos eventos coletivos e nos bairros periféricos, por outro lado, o eros como domínio sombrio da vida coletiva, como impulso criativo, contato vital, ressurge na forma de movimentos de resistência de base comunitarista.

\section{A Sexualidade e a Canção como Formas de Manifestação do Comum}

Na "História da Sexualidade", Michel Foucault (2017, p. 113-123) traça uma genealogia da sexualidade através das construções de discursos na Medicina, na Escola, na Sociologia e na Psiquiatria, tendo como ponto crítico a invenção da sexualidade feminina pela perspectiva neurológica do doutor Jean-Martin Charcot, no final do século XIX, com os estudos da histeria. Os complexos movimentos de aprisionamento da sexualidade têm no período dos séculos XVII ao XIX um importante marco, pois foi ali que diversas instituições sociais travaram embates pela apropriação dos desejos. Por outro lado, os mistérios em torno da sexualidade ajudaram, ao mesmo tempo, a controlá-la e a valorizar aquilo que ali se escondia.

Se a sexualidade tem sido tema da cultura popular, desde o barroco notadamente com Gregório de Matos - até o último hit deste ano, é porque está aí um terreno rico em entraves, mistérios e questões do cotidiano e formação da psiquê coletiva das sociedades.

Hoje, uma das formas mais interessantes de utilização da canção como linguagem popular, considerando-se sua força expressiva poética de nosso tempo e como princípio entoativo da vida popular, se localiza nas diferentes gradações com que a luta LGBTQI+ vem se manifestando. De modo geral, não se trata apenas de uma questão de "comunidade" homoafetiva, mas da sexualidade como um tópico próprio ao espírito do tempo. 
Do ponto de vista da psiquê coletiva, a expressão da nudez e da sexualidade por vias do arquétipo feminino tem se apresentado como discurso de resistência; já na larga história da body art da performance e do happening, até a mais recente expressão nua e crua de MC Linn da Quebrada, cantora transexual paulistana.

\author{
De noite pelas calçadas \\ Andando de esquina em esquina \\ Não é homem nem mulher \\ É uma trava feminina \\ Parou entre uns edifícios, \\ Mostrou todos os seus orifícios \\ Ela é diva da sarjeta, o seu corpo é uma ocupação \\ É favela, garagem, esgoto, \\ E pro seu desgosto está sempre em desconstrução
}

No trecho da música Mulher, vemos o estado de desconstrução constante como condição da sexualidade contemporânea e ao mesmo tempo como "desgosto" por aqueles que conservam o espírito arcaico do século passado.

Na perspectiva maffesoliana, a transfiguração do político se observaria aqui na articulação de uma nova ética fundada na afecção, na estética como a valorização de uma comunicação fundada na emoção coletiva; e, portanto, muito mais que uma estrutura, ela é um "ethos vindo de baixo" (GABBAY, 2017, p. 105). O discurso afirmativo tem encontrado, em meio à ascensão conservadora, formas mais brutais de manifestação ("Mostrou todos os seus orifícios"). Afirmação por meio da presença ("Parou entre uns edifícios"). A presença como fundadora de uma ética comunitária. Eu sou assim, existo assim. Esta forma do discurso não tem mais um ponto de referência no imaginário contratual conservador moderno, mas nos símbolos afetivos de uma nova dinâmica das "artes de dizer", ou seja, na forma cambiante da linguagem do cotidiano (DE CERTEAU, 1990, p. 26-28). Asa palavras "garagem”, “esgoto", "sarjeta”, “orifícios” na letra da canção trazem à tona o espaço negado, a cidadania aviltada, e ao mesmo tempo a ideia de “ocupação", transformação ("E pro seu desgosto está sempre em desconstrução").

As "artes de dizer" do cotidiano consistem em uma maneira de invenção das narrativas sobre uma coletividade que, ao se oporem à dada narrativa hegemônica, apresentam-se como estratégia de resistência, ainda que não programada. Resistência às 


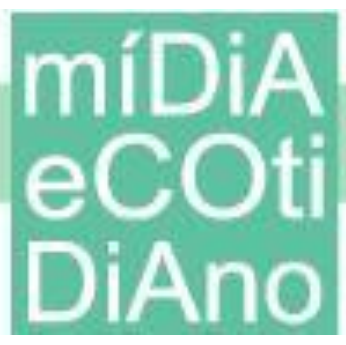

estratégias de legitimação dogmática, o que, no mínimo, instaura um jogo de afirmação e negação, ou ainda, uma dinâmica multilateral de produção de verdades e da história. Mesmo que nesse jogo a distribuição de forças de legitimação seja desigual, como de fato o é, vemos aí a potência transgressora alojada justamente no funcionamento de um processo comunicacional e narrativo alternativo.

Assim, em vários casos, o descentramento do masculino tem sido uma tônica que reúne diferentes graus da militância LGBTQI+. O masculino entendido aqui como arquétipo ligado ao poder, à ordem, à força avassaladora da razão lógica, à figura opressora do pai projetada na escola, na igreja, na mídia, nas instituições, e na praça pública. Digamos que o cimento do vínculo comunitário, no caso das militâncias LGBTQI's seja justamente este descentramento do masculino arquetípico, que representa um desmonte da base simbólica do sistema de poder moderno; caracterizado, dentre tantas imagens, pela cena final do clássico de Francis Ford Coppola de 1972, quando o jovem Al Pacino se torna o novo "padrinho" e a câmera mostra a perspectiva da personagem de Diane Keaton, que assiste à ascensão do novo chefão de fora, arrumando utensílios prosaicos de cozinha. A violência explícita do filme de Coppola, os tiros, mortes, sangramentos, todos os corpos raivosos de homens vingativos e frios, inspiraram uma geração de filmes de gangsters e policiais. O mesmo sentimento retorna em 2002 com o "Cidade de Deus" de Fernando Meirelles. Da máfia italiana às bocas cariocas, o século XX foi marcado pelo derramamento de libido masculina: vingança, rancor e poder.

Por outro lado, o descentramento do arquétipo masculino que se apresenta no cancioneiro popular, ainda iniciático, de certos ícones LGBTQI's não acontece de forma propriamente idílica. O feminino arquetípico não é um clichê angelical (os anjos, aliás, são muitas vezes representação da androginia). Como já sugerimos aqui, o que dá sustento ao comunitário é a "sujeira” produzida no cotidiano, o desvio, a transgressão, o desacordo. $\mathrm{Na}$ analogia do desvio, o psicólogo e rabino brasileiro Nilton Bonder (1998) sugere que, na arqueologia mística judaica, o corpo representa a estrutura conservadora e a alma representa o impulso transgressor; de modo que é da natureza humana, seja do ponto de vista teológico, como histórico-materialista, transgredir.

Pois foi justamente o "segundo mundo" (BAKHTIN, 2013, p. 5), marcado pelo espírito transgressor da comicidade carnavalesca, o espaço visado pelas instituições 


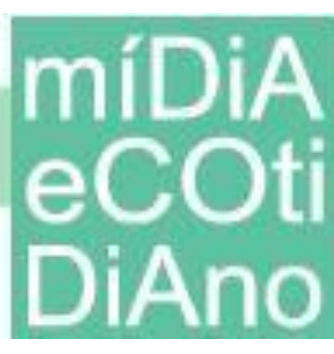

depois da Idade Média. Mas no universo poético de François Rabelais, a vida popular seria marcada pelos arquétipos do carnaval: subversão da ordem, dos papéis sociais, uma maior evidência do baixo e do grotesco. A diferença em Bakhtin é que a carnavalização na poética de Rabelais não se distancia da vida popular para ocupar um espaço institucionalizado. Ali, o carnaval é uma "segunda vida", onde impera "um tipo particular de comunicação, inconcebível em situações normais" (BAKHTIN, 2013, p. 9-15). As formas de falar, linguajar, gestual, corpo, são essencialmente transgressoras, transmutantes e baixas.

Em "Pajubá", disco de 2018 de Linn da Quebrada, a música Enviadescer, cujo título reúne os sentidos de entrar, tornar-se "viado" e descer, indica um retorno a um corpo transgressor. Na perspectiva mitológica de Nilton Bonder, como mencionamos, o corpo conserva e a alma transgride; no entanto, é a tensão entre os dois que produz as grandes mudanças no mundo e na psiquê coletiva. Um corpo transgredido e transmutado é um corpo em estado de dolorosa tensão. Pois no final da música, o eu-poético dirige-se ao "macho-alfa", símbolo máximo do conservadorismo moderno, e indica a violência com que se conquista a liberdade nos versos "já quebrei o meu armário / e agora vou te destruir", para finalmente assumir uma imagem comumente mais provocativa das identidades de gênero: o travesti.

\footnotetext{
Enviadeci, enviadeci

E agora, macho-alfa, Não tem mais pra onde fugir

Enviadeci, enviadeci Já quebrei o meu armário

E agora vou te destruir

Porque antes era viado,

Agora eu sou travesti
}

Transgressão como atravessamento agressivo, impulso criativo. A criação como ruptura. Assim, o comunitário, em tempos de crise, se coloca cada vez mais como espaço de ruptura, de transgressão e de desacordo. Dizer que o desacordo é salutar parece óbvio. É na discordância que crescemos e desenvolvemos o pensamento. Mas, para além desta visão idílica da discordância, acreditamos na comunidade como espaço de embate. Como vimos, a fala cotidiana produz estruturas comunicacionais ao mesmo tempo 


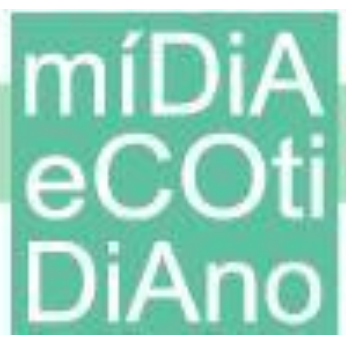

intensivas e reduzidas no espaço (MAFFESOLI, 2006, p. 126). Mas é na intensidade afetiva que repousa uma esperança do discurso. Discurso como uma espécie de encarnação poética da violência cotidiana.

Assim, as várias dúvidas, os incômodos e desentendimentos em torno do que o senso comum entende como "comunidade gay" se expressam hoje na extensa e cambiante sigla que procura abraçar a causa. LGBTQI+, deixando aberta, com o sinal de adição, a porteira da comunidade. Nesse “+” parece caber todo tipo de autodenominação, de descoberta e de experiência. A sigla é ao mesmo tempo espaço de acolhida e de transgressão, cujo elo vinculativo é, insisto, o descentramento do arquétipo masculino.

Uma concepção bem diferente daquela erguida pela sociologia estruturalista. Ali, comunidade era estabilidade, terreno fechado, fronteira, templo. Na medida em que $\mathrm{o}$ arquétipo feminino, tradicionalmente ligado à ideia de casa, útero, alimento e permanência, vem mostrando suas outras faces, ligadas ao conflito, à devoração e ao parto, o sentido de "comunidade" também precisou ser revisto.

Comunidade hoje é espaço de desacordo. E isso não é um demérito. Pelo contrário. Assim, dentro da grande-mãe que é a sigla LGBTQI+, existem pendências sérias entre gays e bissexuais, entre lésbicas e transexuais, entre queers e travestis. Cada grupo buscando entender onde está a sua porteira, quem são seus irmãos de comunidade. Há momentos em que é preciso ampliar o terreno e fazer da sigla um grande campo de resistência. E há momentos em que é preciso perguntar ao forasteiro: “quem és tu?”, “o que fazes aqui?", porque muitos desejam o colo materno da comunidade; mas, como sabemos, a entrada na comunidade requer sacrifício. Ainda que, como arquétipo materno, a comunidade tenha se transfigurado, ela ainda mantém suas características fundamentais, quais sejam, a acolhida, o espaço de vínculo afetivo, e a adesão (seja por afetos, gostos, ideologias, etc). A adesão requer uma tomada de posição, que hoje muito se dá pelo discurso - tema profundamente associado à herança de Foucault (2007). Daí a necessidade de reconhecer os partícipes da comunidade, os iniciados, as lideranças. Essas posições não desaparecem, mas se transfiguram, se deslocam e se projetam. É assim também com os trovadores de nosso tempo, os artistas populares. Aqueles que se aproximam da comunidade para se colocarem como porta-vozes por meio do mais vibrante mecanismo de discurso contemporâneo: a canção. 
Uma geração de cancionistas veio se apresentar à comunidade. Johnny Hooker, Liniker, Pablo Vittar, Aíla, Linn da Quebrada. Outra geração se viu na posição de iniciados ou patronesses: Ney Matogrosso, Caetano Veloso, Elza Soares. Num contexto mais contemporâneo, as tensões travadas no interior do cotidiano e das lutas de resistência tomam formas arquetípicas mais amplas, onde a cantora transgênero Liniker representa uma liderança simbólica. Assim como o ex-Deputado Federal do PSOL Jean Willys, que entrega boa parte de sua imagem pública à luta pelos direitos LGBTQI's. Trata-se sempre da necessidade de projeção ampla da figura do porta-voz, daquele que profere o discurso da comunidade. Este discurso podendo ser proferido como corporeidade, como presença - A cantora dragqueen Pablo Vittar declarou à revista Rolling Stone ${ }^{6}$ de janeiro de 2018 acreditar que sua presença era mais potencialmente política que sua música - ou como discurso na forma canção.

Numa escala global massiva, o icônico álbum Lemonade, de Beyoncé (2017), foi consumido como uma espécie de hinário ou manifesto para uma geração de jovens meninas negro-americanas que projetaram ali seu próprio processo de reconhecimento. O Lemonade de Beyoncé acabou virando o discurso sonoro do boom de vídeos de big chop no Youtube; o ato em que meninas negras raspam os cabelos alisados para que cresçam crespos, e filmam o processo para que oriente outras meninas, numa espécie de comunidade virtual global de ativismo negro manifestado pelo símbolo cabelo. Também a canção-vídeo This is America, de Childish Gambino exerceu semelhante efeito nos grupos de militância racial, provocando furor ao encenar uma miríade de detalhes da história da colonização branca nos Estados Unidos e os fundamentos do racismo americano. No mesmíssimo período, Beyoncé voltava à Internet, dessa vez acompanhada por Jay-Z para encenar a canção-vídeo Apeship; uma denúncia do domínio branco nas artes eruditas e da condição subalterna do negro no imaginário europeu, coreografada pelo dançarino belga-marroquino Sidi Larbi Cherkaoui. Gravado no Museu do Louvre, o vídeo põe em conflito o belo como erguido à moda europeia por meio de uma presença em tonalidade agressiva de Beyoncé e Jay-Z. Cherkoui comenta: "Inside of tension

\footnotetext{
${ }^{6}$ Disponível em: <https://rollingstone.uol.com.br/edicao/edicao-137/pabllo-vittar-capa-no-vicio-dabatida/>. Acesso em: 07 jun. 2019.
} 


\section{míDiA

there's always release, and inside of release there's always a bit of tension" "7 Tensionar é descentrar mais uma vez o domínio do colonizador, seus arquétipos encarnados na pele branca, nos traços delicados do realismo europeu. Arquétipos que se apresentam fatalmente como força anticomunitária se colocados em perspectiva política diante das comunidades de resistência racial e de gênero.

Do ponto de vista da produção do comum e das narrativas da comunidade, interessa aqui menos o aporte mercadológico da canção e muito mais as formas de uso da música popular como dispositivo de expressão e de vinculação comunitária tribal. Em torno de um discurso sonoro, de sua contundência no campo da linguagem não-verbal e de sua representatividade, acimentam-se grupos, coletivos, ações e relações afetivas.

E é característico desta geração de porta-vozes e cronistas da luta comunitária a linguagem popular em seu sentido mais contundente. As grosserias, blasfêmias, ambivalências, palavrões e obscenidades; todas as "expressões verbais proibidas e eliminadas da comunicação oficial", que caracterizam o "realismo grotesco", alertava Bakhtin (2013, p. 15-17). Basta lembrar que o último hit de Beyoncé e Jay-Z, como vimos acima é intitulado com a corruptela de um palavrão: apeshit. Mas por "realismo" não entendamos uma função descritiva da linguagem, mas sim uma ruptura do "real"; um outro real. A baixaria que hoje encontramos no cancioneiro popular como recurso poético - e é fundamental salientar aqui que nos interessa a linguagem poética de motivação popular em detrimento daquela cuja estrutura persegue primordialmente as tendências do mercado - carrega uma função de retorno à comunidade.

O rebaixamento grotesco no popular sugere tanto um retorno ao parto, ao nascer, como à escuridão da gruta, o mundo subterrâneo da vida popular. E assim como Bakhtin (2013, p. 19; 30-33) esforça-se para distinguir o grotesco popular em Rabelais do grotesco romântico dos alemães do Strum und Drang, há de se separar o grotesco desviante e poético das militâncias comunitaristas LGBTQI's daquele apropriado e instrumentalizado pelo mercado; pois, reforça Bakhtin (2013, p. 45), só no domínio do

\footnotetext{
${ }^{7}$ Disponível em: <https://pitchfork.com/thepitch/choreographer-beyonce-jayz-apeshit-video-interviewinspired-by-mythology-martha-graham/>. Acesso em: 07 jun. 2019.
} 
popular o infame, o sarcasmo e o riso do realismo grotesco carregam uma "força regeneradora".

Por fim, como vimos, o pensamento maffesoliano, em seus desdobramentos e atravessamentos, nos lega a necessidade ainda iniciática de observar, com olhos atentos, as várias formas de transfiguração da ação política, do comunitarismo, das formas do social e dos vínculos em toda diversidade de manifestações do popular e do cotidiano. É certo que, na perspectiva própria à crítica da indústria cultural, o grotesco serve historicamente como espaço de investimento para manipulação e enfraquecimento político da vida popular (SODRÉ, 1977). Mas a transfiguração é uma ideia que sugere justamente um retorno. Retorno às profundezas da vida comum. Retorno à baixeza da vida popular, onde o grotesco recupera sua força vinculativa e subversiva. Este é um movimento lento, microscópico, oprimido, mas possível enquanto modelo de linguagem e de comunicação popular. É preciso exercitar um olhar de baixo, a partir das profundezas da vida comum, e apto a se lançar nas experiências de transmutação de todo discurso cristalizado durante os séculos passados. É preciso, afinal, se lançar no fundo das aparências rumo a novas formas de observação sociológica.

\section{Referências}

AGAMBEN, G. Nudez. São Paulo: Autêntica, 2009.

BAKHTIN, M. A Cultura Popular na Idade Média e no Renascimento. São Paulo: Ed. Hucitec, 2013.

BONDER, N. A Alma Imoral. Rio de Janeiro: Rocco, 1998.

BUBER, M. Sobre Comunidade. São Paulo: Ed. Perspectiva, 2008.

DE CERTEAU, M. L'invention du quotidien: 1. arts de faire. Paris: Gallimard, 1990. FOUCAULT, M. A ordem do discurso. São Paulo: Ed. Loyola, 2007. História da Sexualidade: vontade de saber. Rio de Janeiro: Paz e Terra, 2017.

GABBAY. M. Música Popular e Comunicação Poética. Curitiba: Appris, 2017. 
GENDRON, G. Les boubours, bobos à rebours. In: Journal Libération, Paris, 8 dez. 2016. Disponível em: <http://next.liberation.fr/vous/2016/12/08/les-boubours-bobos-arebours_1533938>. Acesso em 07 jun 2019.

HAN, B. Agonia do Eros. Petrópolis: Ed. Vozes, 2012.

KIERKEGAARD, S. Temor e tremor. São Paulo: Livraria Exposição do Livro, 1964.

MAFFESOLI, M. A Sombra de Dionísio. São Paulo: Ed. Zouk, 2005a.

O mistério da conjunção: ensaios sobre comunicação, corpo e sociabilidade.

Porto Alegre: Sulina, $2005 b$.

A Transfiguração do Político. Porto Alegre: Sulina, 2005c.

O tempo das tribos. Rio de Janeiro: Forense Universitária, 2006.

Matrimonium: petit traité d'écosophie. Paris: CNRS, 2010.

Homo Eroticus: des communios émotionnelles. Paris: CNRS Éditions, 2012.

Les nouveaux bien-pensants. Paris: Éditions du Moment, 2013.

MARCUSE, H. (1977). A Dimensão Estética. Lisboa: Edições70, 2007.

SODRÉ, M. A Comunicação do Grotesco. Petrópolis: Vozes, 1977.

As Estratégias Sensíveis. Petrópolis: Ed. Vozes, 2006. 